\title{
INTRODUCTION: FALSEHOOD IN WARTIME
}

\author{
Edward Timms and Fred Bridgham
}

The early twentieth century was the great age of the newspaper press, as mass literacy endowed the printed word with unprecedented power. Newspaper production was revolutionized by rotary presses and linotype compositing machines, while modern roads and railways, together with the telephone, telegraph, and teleprinter, were transforming communications. In Western Europe and North America democratic institutions, social reforms, and scientific discoveries seemed to be laying the foundations for a new era in the history of mankind. But it was also a period of intense imperial rivalries, backed by highly trained forces and sophisticated armaments industries. Given the precarious international situation, it was possible at moments of crisis for journalists to tip the balance between peace and war. Liberal papers such as the Manchester Guardian (edited by C. P. Scott) and the New York Times (under Adolph Ochs) may have been committed to the peaceful resolution of conflicts, but wars were good for newspaper sales. Moreover, wealthy proprietors like Hearst and Northcliffe, Hugenberg and Benedikt, were imperialists capable of pressurizing governments into declarations of war.

Almost alone in the period before the First World War, the Viennese satirist Karl Kraus saw the press as an apocalyptic threat. In his magazine Die Fackel (The Torch), founded in April 1899, he would reprint prize examples of newspaper propaganda and expose their falsification of reality. ${ }^{1} \mathrm{His}$ witty diatribes attracted a large readership, and with a print run of over 10,000 copies the magazine proved viable without having to rely on commercial advertising. To protect his independence Kraus created his own imprint, Verlag Die Fackel, which published book editions of his writings.

Where the editorials of the leading Austrian daily, the Neue Freie Presse, were celebrating the advances of German culture and the triumphs of European civilization, Kraus would expose the realities of conflict and suffering. He had a gift for dissecting the cliché-ridden language of his contemporaries. Sonorous metaphors like "standing shoulder to shoulder" evolved into satirical leitmotifs, culminating in his indictment of the anachronistic ideals that sustained 
the Central Powers during the First World War. His own style, by contrast, was enlivened by an aphoristic wit and moral fervour that left his readers uncertain whether to laugh or cry.

The apocalyptic tone of Kraus's bleakest visions appeared to leave little hope for mankind. Borrowing from the Bible in a prophetic essay entitled "Apocalypse", published in October 1908, he identified Kaiser Wilhelm II as an "apocalyptic horseman" with the power to destroy the peace of the earth. ${ }^{2}$ Moreover, the dangers arising from autocratic power were intensified by a technology that was running out of control: "ultimately, mankind lies dead beside the machines it has created, incapable of putting them to constructive use because so much intelligence has been expended on inventing them" (F 261-62, 1-5). This foreshadows the critique of mechanized warfare in Die Fackel of 1914-18, but it would be wrong to see Kraus's satire as exclusively negative. It drew on a conception of human dignity shaped by the moral vision of Kant and the cultural ideals of Goethe. The satire of Die Fackel, which Kraus wrote single-handed from 1912 onwards, combined analyses of impending disaster with the advocacy of a better world.

Kraus was born on 28 April 1874 as the son of a prosperous Jewish paper manufacturer. Growing up in Vienna, he had to contend with the pressures of a deeply conservative and stridently anti-Semitic environment. A recent study by Paul Reitter has identified undertones of Jewish self-hatred in Kraus's “antijournalism." ${ }^{3}$ His writings are certainly shaped by the impulse to construct an identity free of allegedly negative "Jewish" characteristics, but this is by no means the whole story. A further apparent constraint arises from the fact that Kraus's satire is basically a collage of quotations, framed by his own ironic commentaries. This means that much of Die Fackel consists of reports clipped and reprinted from the newspapers of his day. This quotation technique gives his writings their historical density, but it would be wrong to see them as parochial. His satire certainly emerged from a specifically Austrian Jewish milieu, butlike the work of Freud and Herzl, Mahler and Wittgenstein - it has far-reaching implications.

\section{How Is the World Governed and Made to Fight Wars?}

During the years 1908-14 Kraus's critique of the press acquired a new urgency as he highlighted the threat of war. The Austrian annexation of BosniaHerzegovina precipitated a crisis in the Balkans, provoking a fierce reaction in the Serbian capital, Belgrade. By March 1909 the Austro-Hungarian army was poised to invade Serbia, hoping by this means to crush the political aspirations of the South Slavs within the borders of the Habsburg Empire. However, 
the government needed to find a moral justification for war and thus to ensure that the conflict remained localized. The Austrian Foreign Ministry accordingly orchestrated an anti-Serbian campaign, finding a willing ally in the patriotic historian Heinrich Friedjung. On 25 March 1909 the Neue Freie Presse published an article by Friedjung which purported to justify military action. Drawing on documents supplied to him by the Foreign Ministry, he accused members of the Croatian Diet (the administration of one of the Hapsburg provinces) of a treasonable conspiracy with the government in Belgrade.

This article was intended as a fanfare for war, but at the last moment, under pressure from Russia, the government of Serbia backed down. The threat of war receded, and in place of the intended humiliation of Serbia it was Austrian foreign policy that was put on trial. Members of the Croatian Diet brought a libel action against Friedjung, which Kraus regarded as so important that he attended in person. The trial, which lasted fourteen days, was fulsomely reported in the Neue Freie Presse. It began with patriotic bluster as Friedjung produced copies of his documents, which identified the alleged conspirators by name. One of those named, Bozo Markovitch, a university professor in Belgrade, was surprised to discover from reports of the trial that he had held secret meetings with the Croatian conspirators and induced them to accept treasonable payments. Risking arrest, Markovitch travelled to Vienna to testify that at the time of the alleged meetings in Belgrade he had actually been in Berlin, attending lectures on jurisprudence. This testimony was greeted by judge and jury with incredulity - until the Prussian police, famous for their meticulous record keeping, confirmed that Markovitch had indeed been in Berlin at the time of the alleged conspiracy. The documents were exposed as forgeries and Friedjung was humiliated.

Kraus responded with a trenchant analysis of the Friedjung trial, exposing the irresponsibility of the Foreign Ministry and the susceptibility of public opinion. "In a deluded world", he wrote, "Austria is the last to lose its credulity. It is the most willing victim of publicity in that it not only believes what it sees in print, but also believes the opposite, if it sees that in print too" (F 293, 1). The case provided him with a model of political mystification, showing that the patriotic fervour whipped up by the press by no means lost its hold when its fraudulence was exposed. In other contexts Kraus may understate the role of governments as instigators of political mystification, treating the press in isolation, as if it were an independent force for evil. Here he does justice to all the main factors: the government as instigator, the press as its willing agency, the collusion of intellectuals, the gullibility of readers, and the impact of jingoistic slogans. He makes the probable consequences equally clear: a war in which thousands of lives will be lost. 
Kraus's article has a paradigmatic value with applications for our own day. In 1909, when Friedjung claimed that Austria was "in danger", citing forged documents in an attempt to stage a war, his lies were exposed in court. Sadly, the political lesson was not learnt, and the warmongers ultimately had their way. Moreover Kraus's analysis has a prophetic resonance. Almost a hundred years later, the evidence used to justify the invasion of Iraq in 2003 proved to be just as flawed as that cited by Friedjung. The photographs of Iraqi bases allegedly equipped with weapons of mass destruction, displayed by the U.S. Secretary of State at the United Nations in order to win support for the invasion, owed more to slick public relations than to reliable intelligence. It was now America that was "in danger" and Britain that was standing "shoulder to shoulder" with the dominant military power.

Far from resolving the Balkan crisis, the Austrian annexation of Bosnia was followed by a series of further conflicts, accompanied by equally irresponsible press coverage. Through a close focus on journalistic style, Kraus showed that the language of politics had lost its clarity and flexibility, becoming overloaded with anachronistic metaphors. Hence the increasingly prophetic tone of his critique of Austrian affairs: "On occasion", he wrote in December 1912, "an operetta culture will start parading its enthusiasm for war. Its mercenaries are writers. Totally irresponsible types, who launch a première one day and a war the next" (F 363-65, 71). The example Kraus cites on the following page highlights the irresponsibility of cartoonists, notably Fritz Schönpflug, co-founder of the humorous weekly Die Muskete (The Musket). Schönpflug was famous for his facetious images of the Austro-Hungarian army, such as his drawing of General Staff officers from the Autumn Manoeuvres (Herbstmanöver) series, reproduced here.

Even the adjutants of the portly army commander are equipped with anachronistic sabres and implausibly elegant uniforms, as if they were characters from an operetta. Austrian officers were permitted to wear this paraphernalia when off-duty, and the Schönpflug drawing cited by Kraus in December 1912 portrays them in an urban context: on the Ringstrasse in Vienna. Pleasure-seeking officers are planning a supper party with their friends at a favourite Viennese restaurant. The jocular dialogue with which Schönpflug embellishes his design reveals that it is actually a disguised advertisement-for the Hopfner restaurant chain. These casual exchanges may sound harmless, but for the satirist they epitomize the mindless hedonism of Austrian public life under the shadow of war. Hence the paradox with which his commentary concludes: "An advert for a restaurant? No, a report from the battlefront!" ( $\mathrm{F}_{3} 6_{3}-65,72$ ).

In the following issue, still echoing with the threat of war, Kraus laments 


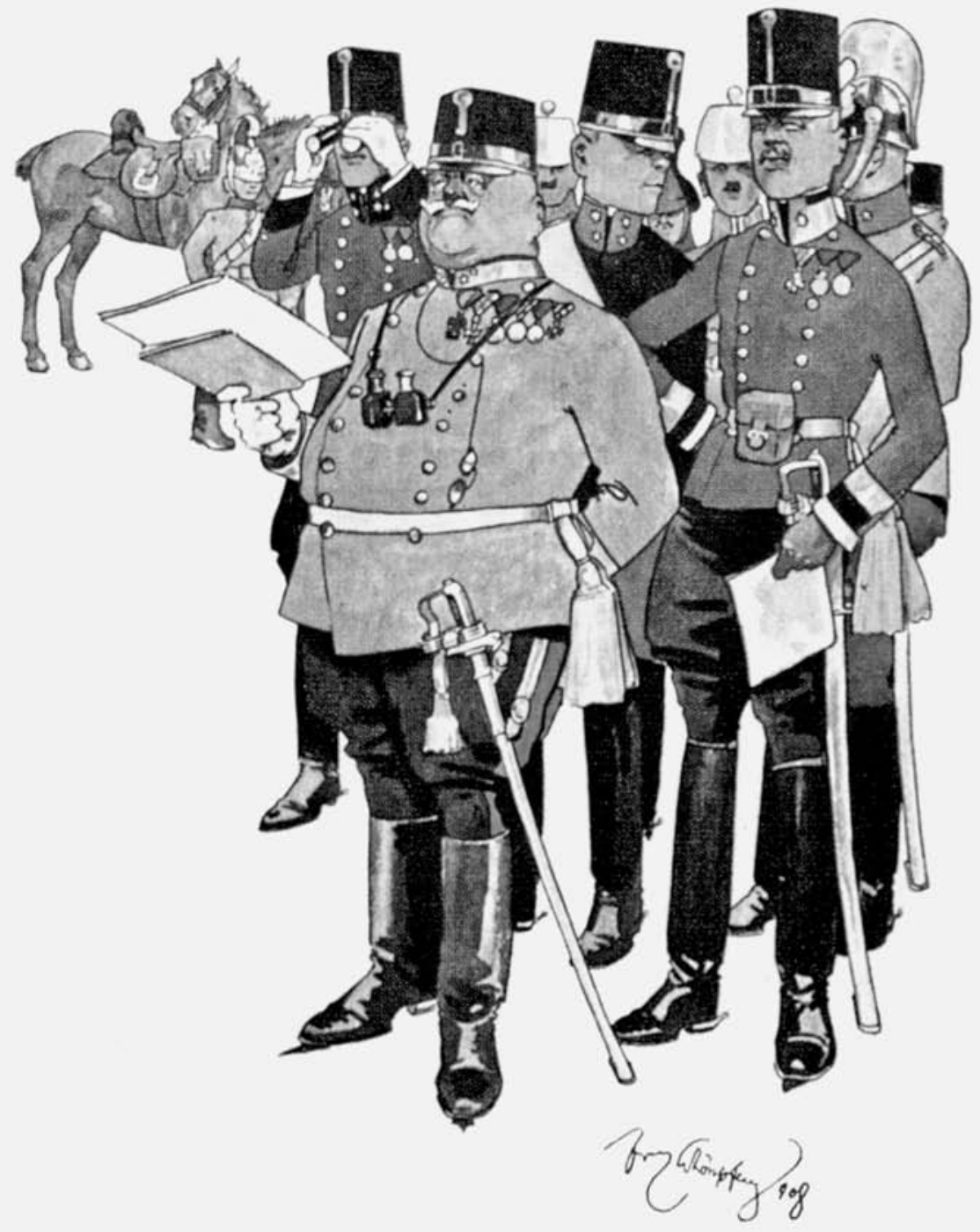

Drawing of General Staff officers from the Autumn Manoeuvres (Herbstmanöver) series 
that Austrian affairs now resemble a botched Schönpflug drawing (F 366-67, 13). He treats the cartoons as a prism through which the tensions destabilizing the Habsburg Empire can be seen in lurid colours. To understand this reaction we need to take account of the cultural politics of the period. Schönpflug and his fellow cartoonists did not merely create figures of fun to distract their readers from an impending crisis. During the years 1908-14 Die Muskete contributed to international tensions by repeatedly publishing xenophobic caricatures of Austria's potential adversaries, especially the political and military leadership of Serbia. Set against patriotic images of the Austrian armed forces would be caricatures of conniving and despicable Serbs. Thus on 15 April 1909, after the government in Belgrade was compelled to accept the annexation of BosniaHerzegovina, Schönpflug's cover design for Die Muskete, ironically entitled "Peace!", portrayed a humiliated Serbia being comforted by Britain and Russia. The Serbs, the cartoon implies, are still hoping for a war against Austria. Hence the caption: "Something postponed may still be condoned."

Historically even more significant was Schönpflug's cover design for the issue of Die Muskete published on 16 July 1914, shortly after the assassination of Archduke Franz Ferdinand, when the peace of Europe hung in the balance. Under the title "Sarajevo" the cartoon depicts the smirking figures of King Peter of Serbia and Tsar Nicholas of Russia self-righteously washing their hands - in a bowl of blood! The King of Montenegro can be seen gloating in the background. Like Friedjung's forged documents, this inflammatory cartoon seems designed to criminalize Austria's adversaries, providing a pretext for launching a war against Serbia and its allies.

Such cartoons, backed by cynical official communiqués and tendentious editorials, shaped a public response to the assassination of the Archduke that filled Kraus with foreboding. In Die Fackel of 10 July 1914 he compiled a panorama of press clippings to portray an irredeemably dysfunctional society. The prime minister, nominally in charge of national policy, is observed relaxing with members of the cabinet in the Café Pucher, while nightclubs continue to churn out popular entertainment as if no catastrophe has occurred. Die Muskete is again identified as a symptom of Austrian decay-through its blurring of the boundaries between military professionalism and journalistic frivolity (serving officers are writing for the magazine under pseudonyms). This endemic confusion of spheres provokes apocalyptic conclusions. Austria, Kraus warns while paying tribute to Franz Ferdinand, is an "experimental station for the destruction of the world" (F 400-403, 2). The publication of this article was followed three weeks later by the declaration of war on Serbia.

During the First World War, despite the constraints of censorship, Kraus 
was able to publish 19 substantial issues of Die Fackel. His was virtually the only journal in any of the belligerent nations to adopt a critical view of the war from the start and sustain it with increasing vehemence until the bitter end. In 1911 he had been received into the Catholic Church, and his opposition to war was nourished by an underlying religiosity. Resisting the politically orchestrated euphoria that swept through Europe, he launched his antiwar campaign in November 1914 by reading in public a critique entitled "In dieser großen Zeit" (In This Age of Grandeur). ${ }^{4}$

Despite the censorship, Kraus succeeded in publishing "In dieser großen Zeit" the following month. His argument deconstructs the idea that the World War has ushered in a heroic era, as proclaimed by the propaganda apparatus set up in every belligerent country. The telegram, Kraus observes in this critique, is "an instrument of war like the grenade" $\left(\mathrm{F}_{4} \mathrm{O} 4,12\right)$. In order to make the thousands of casualties acceptable, the public was saturated with poems and articles celebrating the ethical value of war and the glory of laying down your life for your country. When Kraus argued that people's minds had been numbed by clichés, he had one slogan especially in mind: "dying a hero's death." Through decades of practice, he argued, "the newspaper reporter has so impoverished our imagination that it becomes possible to fight a war of annihilation against ourselves." A more truthful use of language would reveal the "hero's death as cruel destiny" (F 404, 9-10). During the years 1915-18 he intensified his campaign against the insanity of modern warfare, publishing incisive articles, pithy aphorisms, and plangent poems. Being exempt from army service (due to curvature of the spine), he frequently travelled from his home in Vienna to Berlin and other cities to give further readings criticizing the war. His subversive satire led him to be denounced to the authorities as a traitor.

"When war is declared, Truth is the first casualty", according to the motto chosen by Arthur Ponsonby in 1928 for his book Falsehood in War-Time. ${ }^{5}$ Kraus had arrived at this insight twenty years earlier. His targets, from the very first number of Die Fackel, were "Phrasen" (clichés and slogans) and "Lügen" (deceptions and lies). His analysis of patriotic propaganda acquired an even sharper edge in autumn 1915 when he wrote: "How is the world governed and made to fight wars? Diplomats tell lies to journalists and believe them when they see them in print" (F 406-12, 106). This introduced a subtle conception of mediainduced false memory: the hypnotic power of repetition leads politicians to believe the falsehoods they have themselves put into circulation. The result was a self-generating system of mendacity with disastrous consequences for the future of mankind. 


\section{The Last Days of Mankind}

Kraus's most effective technique was to reprint propagandistic statements from the press, highlighting their fatuousness and barbarity. A similar documentary method is deployed with even greater versatility in his masterpiece, The Last Days of Mankind, conceived in the summer of 1915 and largely composed during the war. In this grandiose satirical panorama journalists and military commanders, politicians and profiteers, are re-created as dramatic characters, mouthing the dehumanizing slogans of the day. The claim that Germany and Austria have "drawn the sword" is ridiculed as a prime example of the way newspaper language disguises the horrors of a war that in reality involves trenches, shrapnel, and poison gas. Kraus's play, which could not be published until after the collapse of the Central Powers, concludes with an apocalyptic vision of the destruction of the earth.

Publication began immediately after the lifting of censorship. The first edition, enhanced by a number of photographs, filled four special issues of Die Fackel, dated November 1918 and April, June, and August 1919. This was followed in 1922 by the expanded book edition, framed by two even more expressive photographs, which also accompany our translation. These photos have both documentary and symbolic value. The frontispiece, which records the scene after the Italian dissident Cesare Battisti was hanged as a traitor by the Austrian authorities, was circulated as a warning against disloyalty to the Habsburg crown. For Kraus, who highlights the complicity between cruelty and the camera, this epitomizes the sadistic attitude towards persecuted minorities.

The subject of Kraus's play is the tragedy of mankind, bent on selfdestruction by the methods of modern warfare, while still clinging to outdated ideals of military heroism and national glory. Interwoven with the cataclysmic action are a multitude of satirical strands, each embedded in its cultural matrix: bungled Austrian diplomacy, aggressive German expansionism, brutal military leadership, the greed of war profiteers, the complicity of international big business, the injustices of martial law, the gullibility of newspaper readers, and above all the sloganizing of the press. The cult of war as an "age of grandeur" is satirized in scene after scene, following the approach defined in the Preface: "The document takes human shape; reports come alive as characters and characters expire as editorials; the newspaper column has acquired a mouth that spouts monologues."

There are numerous scenes that reproduce-as dramatic monologue or tragicomic dialogue - the purple prose that some fanatical patriot or propagandist has perpetrated during the war. Political speeches, military bulletins, news- 
paper editorials, commercial adverts, interviews with public figures, snippets from the gossip columns, chauvinistic sermons, and patriotic songs - the range of sources is remarkable. But this documentary technique is enlivened by an irrepressible satirical imagination. The Preface may suggest that the "most improbable conversations conducted here were spoken word for word; the most lurid fantasies are quotations." But the impact is intensified by scenes that blend documentary transcription with comic invention, punctuated by satirical verse. The play concludes with visionary images projected in cinematic style, followed by a verse Epilogue entitled Die letzte Nacht (The Final Night).

This mixing of modes is evident from the Prologue, set in June 1914 as news of the assassination of Archduke Franz Ferdinand in Sarajevo hits the streets of Vienna. Almost the first figures we encounter are a group of officers on the Ringstrasse planning a supper party at their favourite restaurant-they decide on Hopfner's. "D'ya see the latest Schönpflug cartoon?" one of them asks. The underlying irony is that these officers, who reappear in the opening scene of each Act, are themselves modeled on Schönpflug cartoon characters, reshaped in accordance with the "restaurant/battlefront" paradox formulated by Kraus in December 1912. Their fatuous exchanges now hint at something far more sinister. The Schönpflug drawing they admire might well be that venomous cartoon portraying King Peter of Serbia and Tsar Nicholas of Russia as blood-stained criminals. It is left to our imagination whether the officers are chuckling about that prototype of visual hate speech or some harmless humoresque.

Trivial local responses to cataclysmic events generate a pervasive black humour. As the scene shifts to the Café Pucher, the prime minister, while preparing to issue a communiqué, asks the waiter for a humorous magazine - not Die Muskete but Die Bombe! The tragedy of mankind is indeed being played out by "operetta figures" (as the Preface suggests). Kraus shows an exceptional ear for the rhythms of Austrian vernacular, interspersed with patriotic rant and journalistic verbiage. Each of the five Acts opens in similar style, with crowds convulsed by the cries of news vendors announcing the latest sensation: the euphoria in August 1914 after the ultimatum to Serbia has precipitated world war (Act I); reactions after the Italian declaration of war on Austria in May 1915 (Act II); the Romanian declaration of war on the Central Powers in July 1916 (Act III); and the ultimatum by President Wilson leading to the American entry into the war in April 1917 (Act IV). Within this framework the handling of chronology is flexible (there are already references to Italian treachery in Act I). For Kraus, as he observed in 1917, operates "not with mathematical but with apocalyptic precision" (F 462-71, 171).

The fluctuating fortunes of war on the Southern and Eastern Fronts are most 
vividly reflected in Act V. Gloating over the rout of Italian forces at Caporetto in autumn 1917 followed by the capitulation of Soviet Russia at Brest-Litovsk, an Austrian parliamentarian declares: "We are the victors, and we demand the spoils" $(\mathrm{V}, 3)$. Attitudes in Berlin are even more euphoric as Pan-Germans demand vast territorial annexations at a mass rally $(\mathrm{V}, 7)$. But growing pessimism on the streets of Vienna is reflected in rumours that a desperately weakened Austria-Hungary may be seeking a separate peace $(\mathrm{V}, 17)$. Finally, the collapse of the Central Powers in October 1918 is dramatized by a grandiose drunken banqueting scene at army headquarters $(\mathrm{V}, 55)$.

Kraus's underlying humanism is reflected in the prominence given to the word "Menschheit" ("mankind" or "humanity"), both in the title and in the dramatic chorus, the scenes in which a naively patriotic Optimist discusses the war with the Grumbler, Kraus's raisonneur. One of their most striking dialogues, which deals with attempts to legitimize air raids that kill civilians, offers a further instructive parallel between then and now. Although the aerial destruction of urban areas was a rare occurrence when Kraus wrote this play, his analysis has proved paradigmatic. Experience, the Grumbler observes, should have taught the perpetrators of "murder from the air" that "when they intend to hit an arms dump they infallibly hit a bedroom, and instead of an armaments factory a school for girls." When the Optimist objects that this is not "deliberate", the Grumbler replies: “No, worse than that: fortuitous!” (I, 29). They can't help it happening, so they express regret and do it again.

This analysis has a prophetic ring. On 30 July 2014, at the height of the Israeli-Gaza conflict, the Jabaliya School for Girls was hit by shells that killed refugees sheltering inside. The justification offered by the Israeli Defence Force was that militants had fired mortars earlier that day "from the vicinity of the school." ${ }^{6}$ Clearly, the issues raised by The Last Days of Mankind are with us still. Since Kraus's day there has been an exponential increase in the bombing of urban areas and the casuistry used to justify it. The truth identified by the phrase "murder from the air" is now shrouded in euphemisms like "collateral damage." But even Kraus never imagined a global conflict in which democratically elected governments would intentionally bomb civilian targets like Dresden and Nagasaki, incinerating hundreds of thousands of defenceless people. British politicians of the Second World War spoke of "obliteration bombing" as they set about the task of destroying Germany "city by city", a policy condemned by one of Winston Churchill's most principled critics, Bishop George Bell. ${ }^{7}$

In defending the cause of humanity, Kraus was repudiating nationalistic loyalties and aligning himself with the moral philosophy of the Enlightenment. The overwhelming majority of his countrymen, not least the German-speaking 
Jews, identified themselves with the Habsburg Monarchy and the German Reich. Leading authors like Richard Dehmel and Hugo von Hofmannsthal eloquently endorsed the German and Austrian cause, but Kraus took a very different line. If patriotism meant supporting the use of poison gas, and if it was treason to repudiate victories gained by this means, then he declared himself to be "one of the greatest traitors of all times" (F 474-83, 43). As his opposition to the war became increasingly vocal, Kraus was denounced as "the leader of defeatism in Austria" (F 501-7, 91).

During one of his wartime public readings in Berlin, Kraus contrasted the fanaticism of Kaiser Wilhelm II with the idealism of Immanuel Kant ( F 474$83,155-56)$. While German nationalists associated the Categorical Imperative with patriotic duty, the satirist endorsed the programme of international reconciliation set out in Kant's essay "On Perpetual Peace." Kant recognized the importance of creating new international institutions. In "Perpetual Peace" he associated war with the state of nature "where no court of justice is available to judge with legal authority." After arguing for a republican constitution guaranteeing equality for all citizens, he suggested that peace could be secured by "a pacific federation." ${ }^{8}$ Implicit in these arguments are the concepts of a League of Nations (with the power to regulate disputes) and an International Court of Justice (to punish breaches of the peace). For over a century after Kant's death such ideas remained utopian, but in 1918, in the new climate created by President Wilson's Fourteen Points, it was finally possible to put these proposals into practice. For Kraus, there was hope for humanity, after all. He greeted Wilson's "immortal deed", the liberation of Europe from military tyranny, as the fulfilment of Kant's “immortal idea” (F 501-7, 113).

\section{Journalistic Spin and Humanistic Education}

Even after the trauma of defeat, the German nationalist press was unwilling to acknowledge that militarism was discredited. European politics of the interwar period were dominated by the ideological struggle between conflicting myths of the First World War, designed not simply to recall the past but to shape the future. The pacifist movement interpreted the conflict as "the war to end wars", while reactionaries cultivated myths of military prowess as the inspiration for a conservative revolution. They remembered the war as they wished it to have been (and as they intended it to be next time round): as a triumph for German military power.

Kraus repeatedly denounced the chauvinistic postwar mentality that threatened to produce further wars. As early as January 1921 he prophetically identified Germany as the country "where the swastika rises above the ruins of the 
global conflagration" (F 557-60, 59). Against this, he defended the independence of the Austrian Republic. Responding in May 1926 to the agitation in favour of "Anschluss" (German annexation), Kraus argued that the hypnotic power of newsprint was creating a "counterfeit reality" in which "nothing is real except for lies." Newspapers in Berlin and Vienna, by appealing to racist conceptions of "Volkstum", were generating a circular discourse that had no basis in any actual political event. To fill the vacuum, the press was recycling slogans deriving from "the latest beer-hall conversations of the two realms." By confusing political identity with biological homogeneity, the media created a frame of reference that was essentially fictitious. But this gigantic apparatus had the capacity to turn "non-events" into "action and death" (F 726-29, 59-61).

In his campaign against mystification Kraus found a kindred spirit in Bertrand Russell, an outspoken critic of British militarism. In July 1931 he quoted in Die Fackel a passage from Russell's Sceptical Essays about the need for teachers to encourage critical thinking:

For example, the art of reading the newspapers should be taught. The schoolmaster should select some incident which happened a good many years ago, and roused political passions in its day. He should then read to the schoolchildren what was said by the newspapers on the one side, and what was said by those on the other, and some impartial account of what really happened. He should show how, from the biased account of either side, a practised reader could infer what really happened, and he should make them understand that everything in the newspapers is more or less untrue. (quoted F 857-63, 71-72)

To counteract these tendencies Kraus transformed political memory into performative art. He excelled at mocking the chauvinists from the public stage, especially by reading scenes from The Last Days of Mankind. Only the Epilogue was staged during his lifetime, but the message of the play was conveyed in condensed form through antiwar poems such as "The Ravens" (from Act V, scene 55) and "The Dying Soldier" (from the Epilogue), which Kraus recited in public on numerous occasions. Another excerpt repeatedly featured in his programmes showed how false memories are constructed. A staff officer on the telephone is dictating a press release about the Austrian fortress of Przemysl, which has been captured by the Russians. The loss of the fortress, the pride of the AustroHungarian army, is now to be played down as insignificant. When this is queried by the journalist at the other end of the line, the Staff Officer replies: "My dear fellow, you can make people forget anything!" The corresponding scene in the following Act takes place after the recapture of Przemysl. This time the press 
release reverses the argument, reaffirming the fortress's strategic importance. When this blatant deception is queried, the Staff Officer's rejoinder shows the same contempt for the public: "You can make people forget anything!" (Act II, scene 16, and Act III, scene 22). In these ludicrous scenes the Staff Officer may appear to be a character from an operetta, but his technique of rewriting history anticipates that of the Ministry of Truth in Orwell's Nineteen Eighty-Four.

Kraus excelled in analyses of specific journalistic devices, some of which retain their exemplary character long after the occasion faded into history. In a further example dating from January 1921 he analysed the dangers of journalistic "spin." In German this idea was commonly applied to devious arguments thought to be derived from Rabbinic Judaism - "der jüdische Dreh." Kraus turned the tables by using the title "Ein christlicher Dreh" ("Christian Spin") to introduce his analysis of the coverage of a debate at the League of Nations by the Catholic Reichspost. A report in this right-wing daily had attributed Austria's enhanced international reputation to the electoral victory of the Christian Social Party. Citing the full text of the debate, Kraus exposed this tendentious report as a "disgraceful forgery" (F 557-60, 63-72).

During the mid-19zos the tone of Kraus's writings became more hopeful as he supported the reforms of the Social Democrats, who were constructing a more egalitarian community in Vienna. Recognizing that the war had left a legacy of nationalist resentment and social deprivation, he actively engaged in the political struggle. It was in the sphere of culture that he became most directly involved, for he shared the Austro-Marxist view of "Bildung" (culture and education) as a force for social renewal. His recitals made a significant contribution to socialist cultural politics, as members accustomed to the tedium of party meetings were roused from their slumbers by his captivating performances. His gift for composing and reciting topical verses, inserted into works by Nestroy or Offenbach, revived one of the most potent of popular traditions, using hardhitting epigrams to clinch the connections between culture and politics.

One of the primary aims of the educational reforms was to remove chauvinistic literature from libraries, and in $1922 \mathrm{a}$ purge was undertaken of books that glamorized militarism, the Habsburg dynasty, and the Catholic Church. Kraus proposed radical new texts for inclusion in school textbooks. In place of the cult of military valour, children should learn about the debilitating effects of war on the civilian population. The need to educate the next generation in an antimilitarist spirit led him to wonder why the reformers had not included any poems from The Last Days of Mankind in their school anthology (F 588-94, 86). This would help to ensure that "little Aryans, when they grow up, would not develop into such big Aryans that they can't wait for a World War" (F 668-75, 58). 
Kraus responded to Hitler's seizure of power in Germany by composing Dritte Walpurgisnacht (Third Walpurgis Night), an incisive analysis of Nazi atrocities compiled during the summer of 1933. It could not be published until after the defeat of Hitler's Germany, and there is as yet no English translation. Kraus did not live long enough to witness the annexation of Austria, followed by an even more apocalyptic Second World War. He died in Vienna of natural causes on 12 June 1936 and lies buried in a Grave of Honour. His most eloquent memorial is The Last Days of Mankind. To mark the play's centenary we now present the complete text in English for the first time, incorporating translation strategies that are summarized in our Afterword and elucidated in the Glossary.

\section{Notes}

1. References to Die Fackel, ed. Karl Kraus (Vienna, 1899-1936), are identified by the abbreviation $\mathrm{F}$ followed by the issue and page number.

2. For a comprehensive account of the apocalyptic themes that shaped Kraus's career, see Edward Timms, Karl Kraus-Apocalyptic Satirist, Part 1: Culture and Catastrophe in Habsburg Vienna (New Haven and London: Yale University Press, 1986), and Part 2: The Post-War Crisis and the Rise of the Swastika (New Haven and London: Yale University Press, 2005).

3. See Paul Reitter, The Anti-Journalist: Karl Kraus and Jewish Self-Fashioning in Fin-de-Siècle Europe (Chicago and London: University of Chicago Press, 2008).

4. For an English translation of "In dieser großen Zeit", see In These Great Times: A Karl Kraus Reader, ed. Harry Zohn (Montreal: Engendra Press, 1976; repr. Manchester: Carcanet, 1984), 70-83. Much as we admire the pioneering translations of Harry Zohn, we feel that "In This Age of Grandeur" comes closer to capturing the resonance of Kraus's title.

5. Arthur Ponsonby, Falsehood in War-Time: Containing an Assortment of the Lies Circulated Throughout the Nations During the Great War (London: Garland, 1928), 11; for an update, see Phillip Knightley, The First Casualty: The War Correspondent as Hero, Propagandist and Myth-Maker from the Crimea to Iraq (Baltimore: Johns Hopkins University Press, 2004).

6. www.newyorker.com/news/amy-davidson/shattered-school-in-gaza-2 (New Yorker, July 30, 2014; viewed August 2014).

7. G. K. A. Bell, "Obliteration Bombing", in Bell, The Church and Humanity 1939-1946 (London and New York: Longmans, 1946), 129-41.

8. Kant's Schriften (Akademieausgabe), vol. 8 (Berlin, 1912), 346 and 356; cf. Kant's Political Writings, ed. Hans Reiss, tr. H. B. Nisbet (Cambridge: Cambridge University Press, 1970), 96 and 104. 